\title{
Effect of average velocity of passenger cars on national annual emission of pollutants
}

\begin{abstract}
The paper presents the results of the study on the sensitivity of the national annual emission of pollutants from passenger cars to their average velocity under the following traffic conditions: urban, rural, and on motorways and expressways. The study was carried out in accordance with the methodology used in the COPERT 4 software. The effect of traffic speed within cumulated categories of passenger cars on the national emission of pollutants was analyzed. The national annual pollutant emission of pollutants was found to be substantially affected by the average car velocity, this effect being largely differentiated due to the character of road traffic. The type of the dependence of the national annual pollutant emission on the average velocity is similar for all substances, especially under traffic conditions in rural areas as well as on highways and expressways. A distinct minimum of the national pollutant emission was found at a velocity of about $70 \mathrm{~km} / \mathrm{h}$ under rural conditions.
\end{abstract}

Key words: motor vehicles, inventory of pollutant emission, COPERT

\section{Introduction}

It is well known, that the performance parameters of internal combustion engines are dependent, sometimes decidedly, on the operating conditions of engines [6, 7]. Emission of pollutants is particularly strongly dependent on engine operating conditions, due to both the values describing dynamic states, and the occurrence of dynamic states $[6,7]$. The emission of pollutants is most sensitive to the engine operating conditions in the case of spark ignition engines [6]. In the case of compression ignition engines, the presence of dynamic states affects highly the emission of particulate matter, especially when fuel input is rapidly increasing $[6,14]$.

The values describing operating conditions of internal combustion engines include [6]:

- engine thermal state,

- parameters characterising the engine work intensity, such as: engine crankshaft speed and, usually, torque output.

The basic process, which determines vehicle engine operation in the stable thermal state, is the process of vehicle velocity $[2,6]$. That is why, the qualitative pollutant emission testing is carried out in road tests, simulating the real world conditions of vehicle use $[2,15]$.

The process of vehicle velocity may vary greatly depending upon the traffic pattern. Typically, the following traffic patterns of vehicles have been distinguished [1-3, 6 , 8-12, 16]:

- urban,

- rural,

- on highways and motorways.

Sometimes, the traffic pattern in the street congestion situation may be disengaged from the model of urban traffic [3].

Therefore, for the purpose of balancing pollutant emission as well as fuel and energy consumption, the state of vehicle engine operation under conditions of traction use can be characterized by the share of road travelled by vehicles under model traffic conditions, and by the value describing the velocity process under model traffic conditions. As this value, taken as a representative zerodimensional characteristics of the process of driving velocity, the value of average velocity is most often adopted $[2,5,6,8-13]$. Other zero-dimensional characteristics of velocity $[6,13]$ were also considered, including, first of all, the average value of the absolute value of the product of velocity and acceleration [2, 6, 13], albeit the above characteristic is applied solely in the cognitive studies, and not in the practical ones.

Practical tests of pollutant emission from vehicle engines, use characteristics which are dependencies of the specific distance emission of pollutants on the average velocity of vehicles [2, 4-6, 9-13]. These characteristics depend on the environmental characteristics of car engines, which relate to the emission of pollutants.

This paper presents the results of a simulation study on the national annual emission from passenger car engines, based on the average velocity under model traffic conditions: urban, rural and on highways and expressways.

The objective of the study - apart from a cognitive one - was also the practical one, as the selection of values of the average velocity of vehicles under model conditions is extremely difficult, owing to the lack of sufficiently systematic results of empirical study, which would allow for a reliable identification of the above mentioned values.

Consequently, it is advisable to estimate the sensitivity of the modelled national annual emission of pollutants emission from motor vehicles to the average vehicle velocity under model traffic conditions.

\section{The COPERT software}

The COPERT 4 [9-11], applied in this study, is the software of preference in the European Union, for inventorying emission from motor vehicles [16]. 
The study was performed for the automotive situation in 2015. Table 1 shows the values for passenger car traffic in 2015 , based on data reported in [1].

Table 1. Values characterizing passenger car traffic in Poland in 2015

\begin{tabular}{|l|c|c|}
\hline $\mathrm{N}_{\mathrm{PC}}$ & {$[\mathrm{mln}]$} & 20.52 \\
\hline $\mathrm{N}_{\mathrm{PC}-\mathrm{SI}}$ & & 14.66 \\
\hline $\mathrm{N}_{\mathrm{PC}-\mathrm{CI}}$ & & 5.86 \\
\hline $\mathrm{p}_{\mathrm{PC}-\mathrm{SI}}$ & {$[\mathrm{km}]$} & 5900 \\
\hline $\mathrm{p}_{\mathrm{PC}-\mathrm{CI}}$ & {$[\mathrm{km}]$} & 12300 \\
\hline $\mathrm{u}_{\mathrm{U}}$ & & 0.37 \\
\hline $\mathrm{u}_{\mathrm{R}}$ & & 0.5 \\
\hline $\mathrm{u}_{\mathrm{H}}$ & & 0.13 \\
\hline $\mathrm{v}_{\mathrm{U}}$ & {$[\mathrm{km} / \mathrm{h}]$} & 31.5 \\
\hline $\mathrm{v}_{\mathrm{R}}$ & {$[\mathrm{km} / \mathrm{h}]$} & 70 \\
\hline $\mathrm{v}_{\mathrm{H}}$ & {$[\mathrm{km} / \mathrm{h}]$} & 120 \\
\hline
\end{tabular}

The remaining parameters of the model were assumed in accordance with those suggested by the COPERT 4 software.

\section{Results of simulation study}

In the paper, the results are presented of three simulations studies - schematic of the studies is given in Table 2.

Table 2. Schematic of studies Nos 1,2 and 3

\begin{tabular}{|c|c|c|c|c|c|c|c|c|c|}
\hline \multicolumn{3}{|c|}{ Study No 1 } & \multicolumn{3}{c|}{ Study No 2 } & \multicolumn{3}{c|}{ Study No 3 } \\
\hline$v_{U}$ & $v_{R}$ & $v_{H}$ & $v_{U}$ & $v_{R}$ & $v_{H}$ & $v_{U}$ & $v_{R}$ & $v_{H}$ \\
\hline \multicolumn{3}{|c|}{$[\mathrm{km} / \mathrm{h}]$} & \multicolumn{3}{c|}{$[\mathrm{km} / \mathrm{h}]$} & \multicolumn{3}{c|}{$[\mathrm{km} / \mathrm{h}]$} \\
\hline 21.5 & 70 & 120 & 31.5 & 50 & 120 & 31.5 & 70 & 100 \\
\hline 23 & 70 & 120 & 31.5 & 60 & 120 & 31.5 & 70 & 110 \\
\hline 25 & 70 & 120 & 31.5 & 70 & 120 & 31.5 & 70 & 120 \\
\hline 26.5 & 70 & 120 & 31.5 & 80 & 120 & 31.5 & 70 & 130 \\
\hline 28 & 70 & 120 & 31.5 & 90 & 120 & 31.5 & 70 & 140 \\
\hline 31.5 & 70 & 120 & - & - & - & - & - & - \\
\hline 36.5 & 70 & 120 & - & - & - & - & - & - \\
\hline 41.5 & 70 & 120 & - & - & - & - & - & - \\
\hline
\end{tabular}

The average velocity of vehicles was assumed as a variable, respectively, under conditions of urban traffic in the study No 1, under rural traffic - in the study No 2, and under conditions of traffic on highways and expressways in the study No 3 .

The results of the simulation study for selected pollutants are illustrated in Figures 1-21.

There is a significant similarity between the characteristics of the vehicle traffic conditions. For urban traffic conditions, the sensitivity of national annual emission is insensitive to average velocity. For traffic rural conditions, there is a clear minimum national annual emission for average velocity of around $70 \mathrm{~km} / \mathrm{h}$. For traffic conditions on highways and expressways, national annual emission is an increasing function of average velocity.

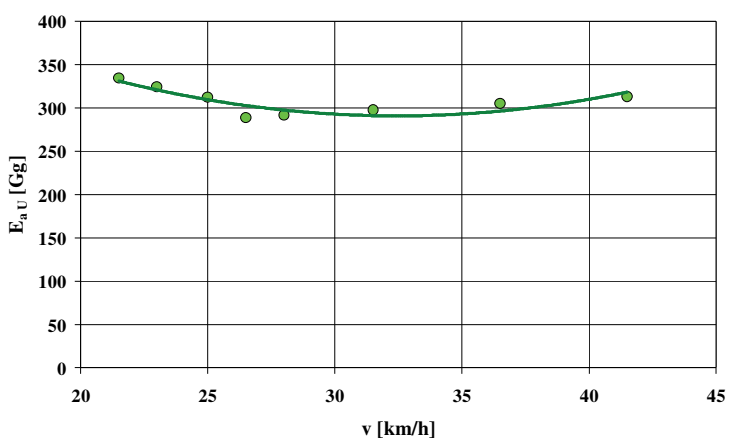

Fig. 1. Dependence of the national annual emission of carbon monoxide from passenger cars upon the average velocity, under model conditions of urban traffic

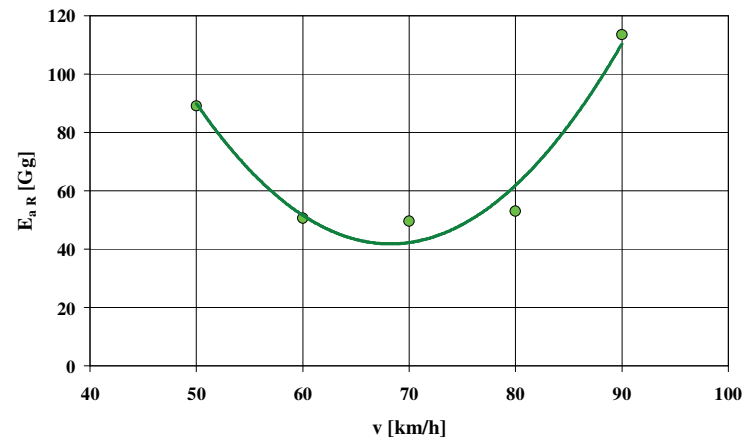

Fig. 2. Dependence of the national annual emission of carbon monoxide from passenger cars upon the average velocity, under model conditions of rural traffic

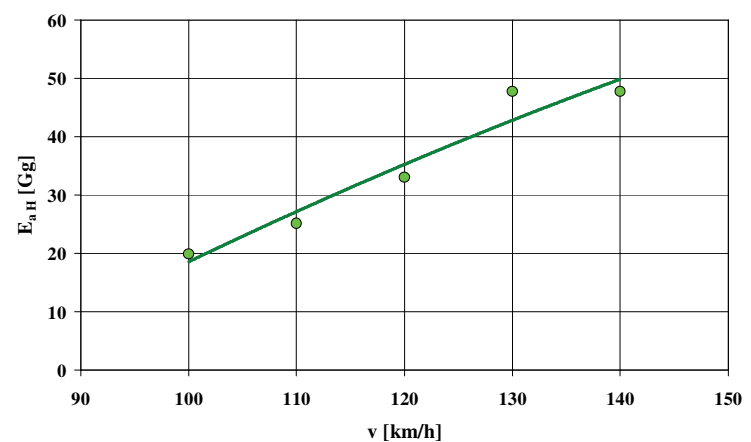

Fig. 3. Dependence of the national annual emission of carbon monoxide from passenger cars upon the average velocity, under model conditions of traffic on highways and expressways

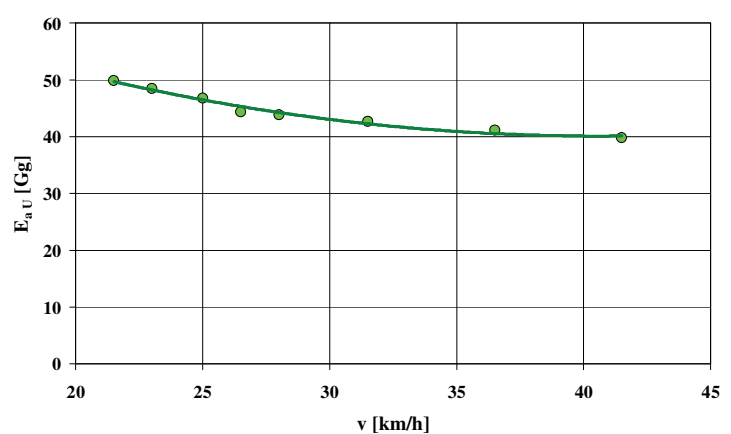

Fig. 4. Dependence of the national annual emission of volatile organic compounds from passenger cars upon the average velocity, under model conditions of urban traffic 


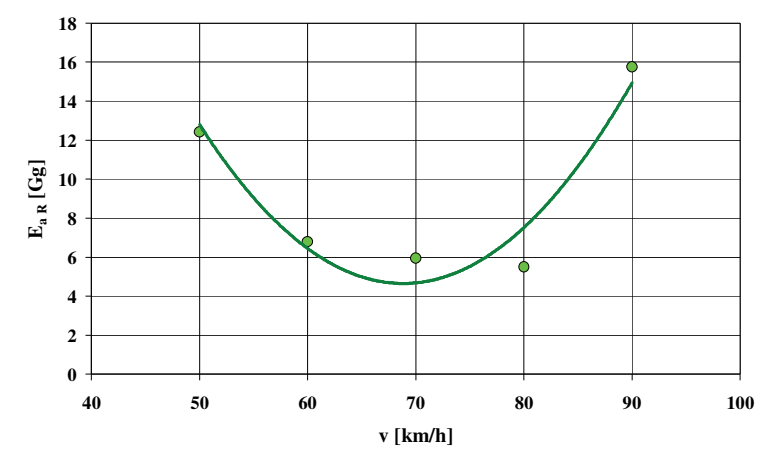

Fig. 5. Dependence of the national annual emission of volatile organic compounds from passenger cars upon the average velocity, under model conditions of rural traffic

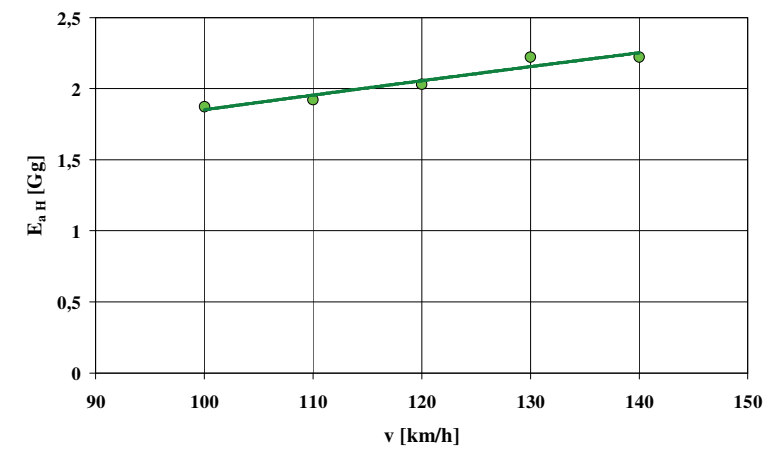

Fig. 6. Dependence of the national annual emission of volatile organic compounds from passenger cars upon the average velocity, under model conditions of traffic on highways and expressways

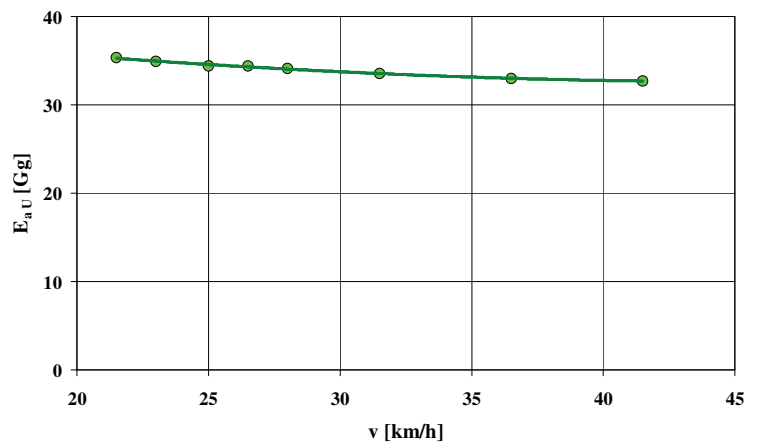

Fig. 7. Dependence of the national annual emission of nitrogen oxides from passenger cars upon the average velocity, under model conditions of urban traffic

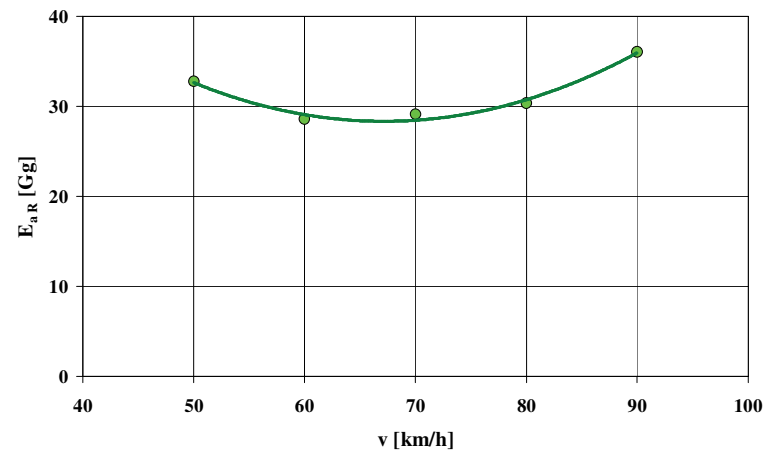

Fig. 8. Dependence of the national annual emission of nitrogen oxides from passenger cars upon the average velocity, under model conditions of rural traffic

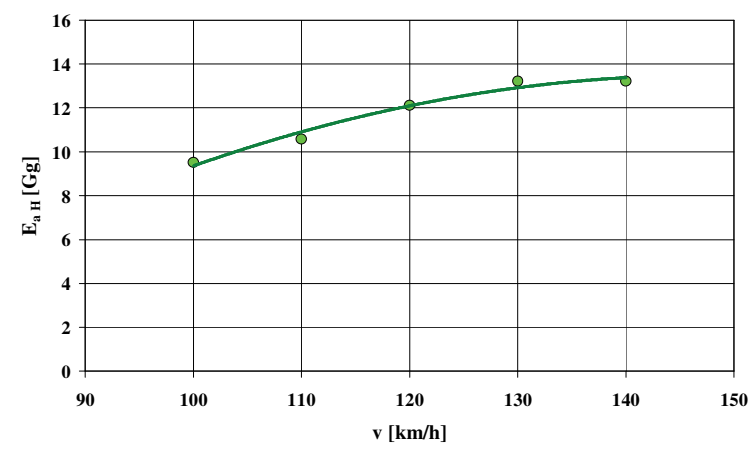

Fig. 9. Dependence of the national annual emission of nitrogen oxides from passenger cars upon the average velocity, under model conditions of traffic on highways and expressways

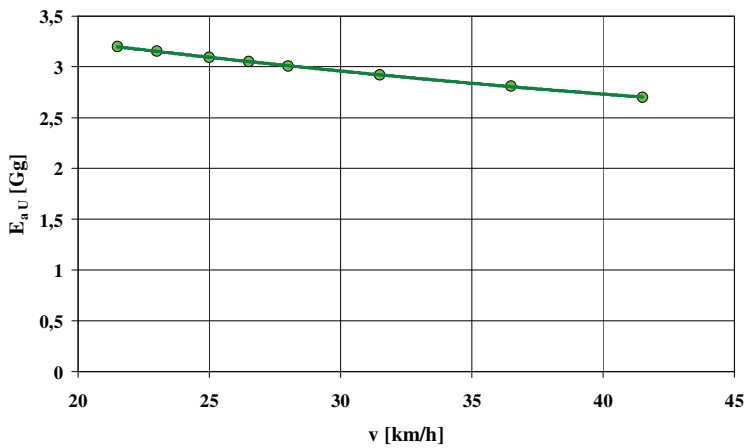

Fig. 10. Dependence of the national annual emission of particulate matter PM10 from tribological elements of passenger cars upon the average velocity, under model conditions of urban traffic

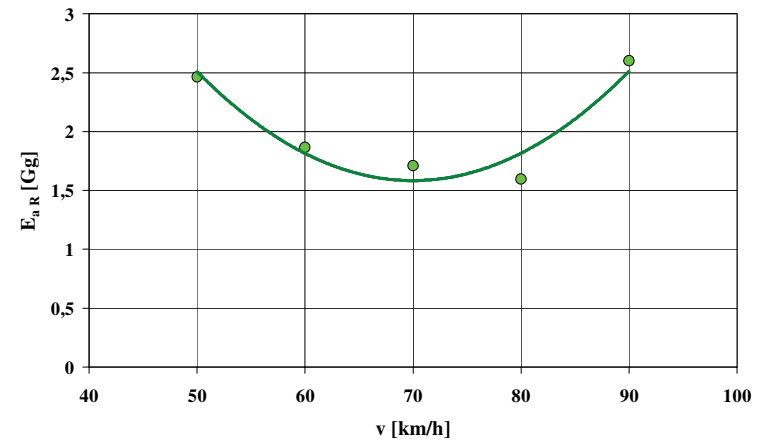

Fig. 11. Dependence of the national annual emission of particulate matter PM10 from tribological elements of passenger cars upon the average velocity, under model conditions of rural traffic

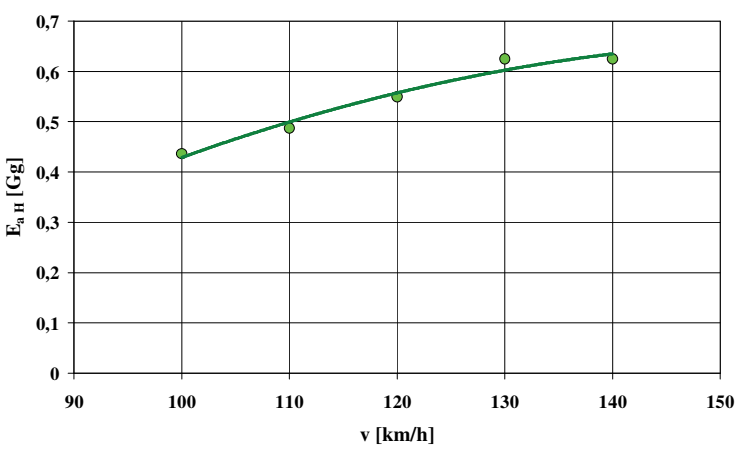

Fig. 12. Dependence of the national annual emission of particulate matter

PM10 from tribological elements of passenger cars upon the average velocity, under model conditions of traffic on highways and expressways 


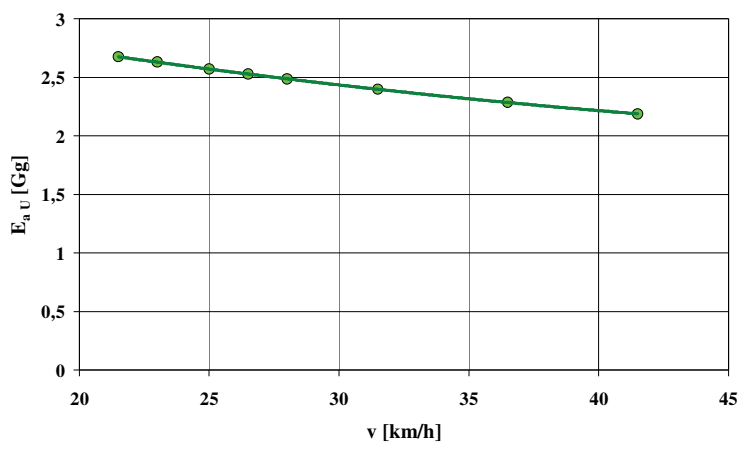

Fig. 13. Dependence of the national annual emission of particulate matter PM2.5 from tribological elements of passenger cars upon the average velocity, under model conditions of urban traffic

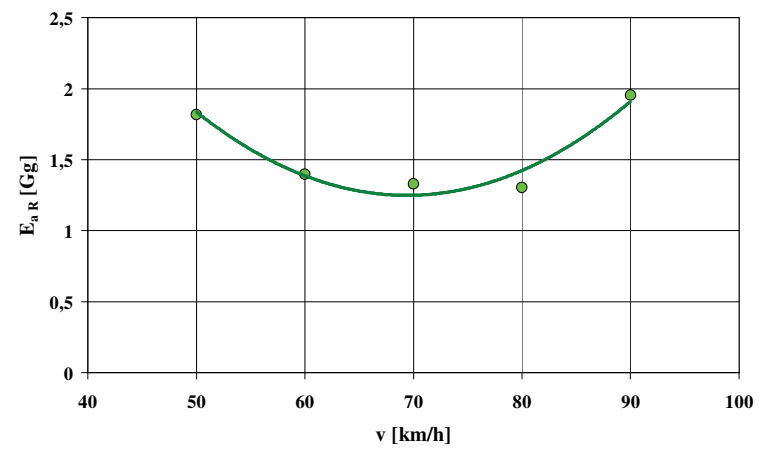

Fig. 14. Dependence of the national annual emission of particulate matter PM2.5 from tribological elements of passenger cars upon the average velocity, under model conditions of rural traffic

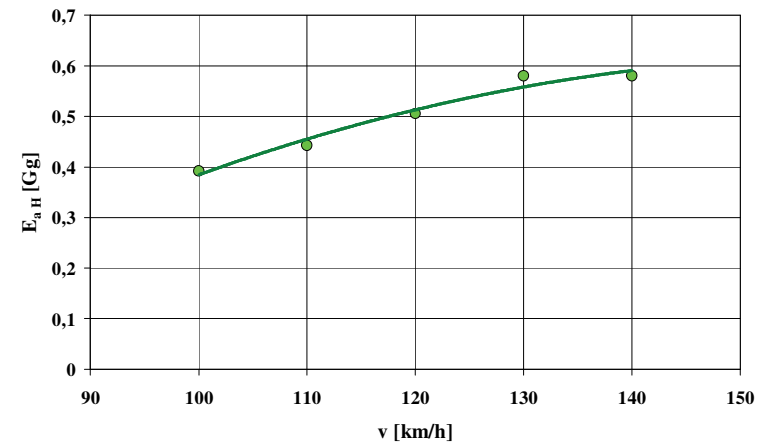

Fig. 15. Dependence of the national annual emission of particulate matter PM2.5 from tribological elements of passenger cars upon the average velocity, under model conditions of traffic on highways and expressways

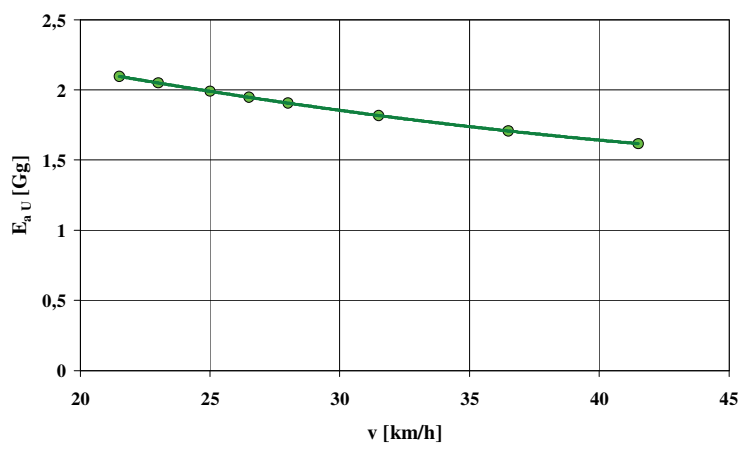

Fig. 16. Dependence of the national annual emission of particulate matter from the exhaust system of passenger car engines upon the average velocity, under model conditions of urban traffic

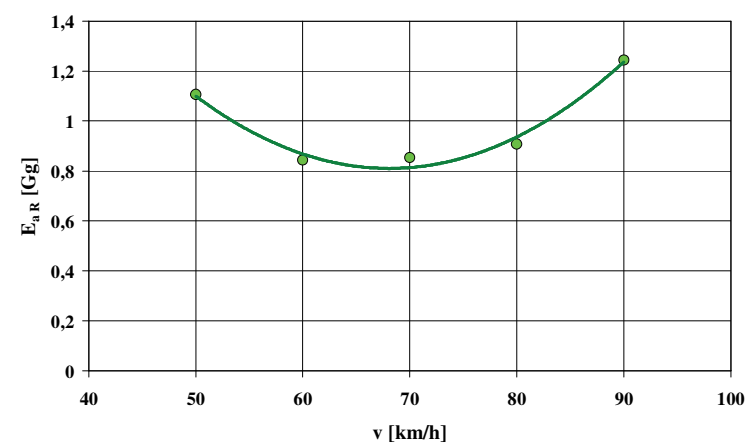

Fig. 17. Dependence of the national annual emission of particulate matter from the exhaust system of passenger car engines upon the average velocity, under model conditions of rural traffic

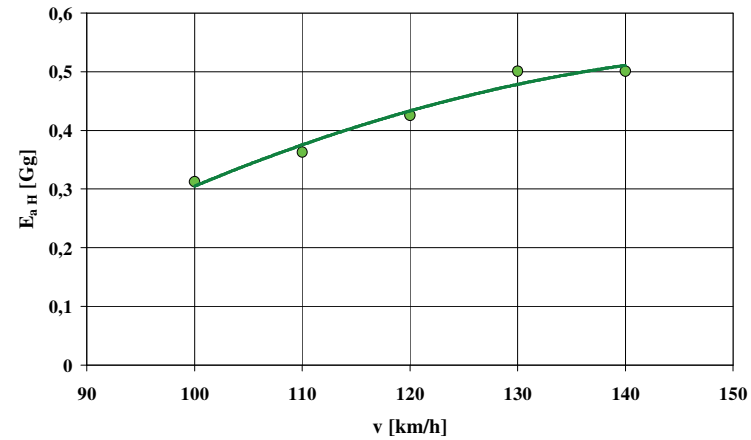

Fig. 18. Dependence of the national annual emission of particulate matter from the exhaust system of passenger car engines upon the average velocity, under model conditions of traffic on highways and expressways

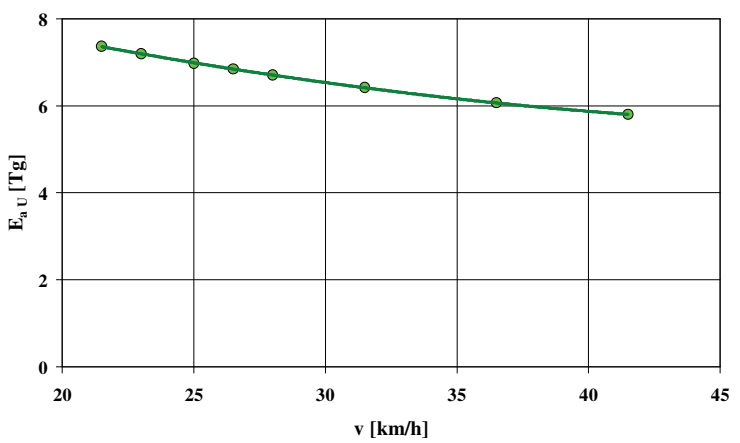

Fig. 19. Dependence of the national annual emission of carbon dioxide from passenger cars upon the average velocity, under model conditions of urban traffic

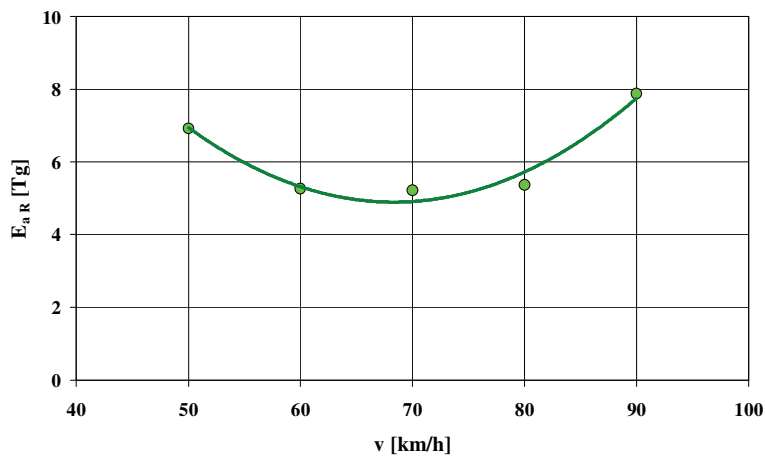

Fig. 20. Dependence of the national annual emission of carbon dioxide from passenger cars upon the average velocity, under model conditions of rural traffic 


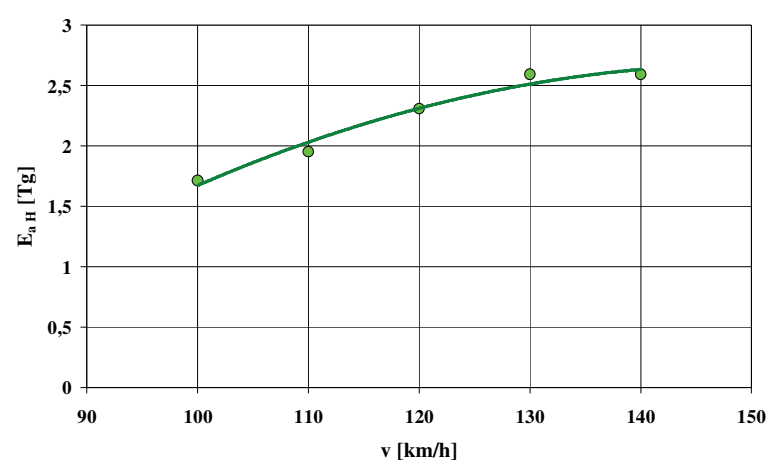

Fig. 21. Dependence of the national annual emission of carbon dioxide from passenger cars upon the average velocity, under model conditions of traffic on highways and expressways

\section{Conclusions}

The simulative study on the dependence of national annual pollutant emission from passenger cars on the average vehicle velocity under model traffic conditions authorize the following conclusions:

1. Despite the differences in the dependencies shown in Figures 1-21, some regularities can be stated. Much smaller differences exist in the characteristics of individual substances than in the conditions of vehicle traffic. There is a substantial similarity of dependence irrespective of pollution type - for traffic conditions: urban, rural, and on motorways and expressways. The most differing dependencies, among the remaining characteristics, are those for the rural traffic.

2. The highest sensitivity of the national annual pollutant emission to the average velocity of road traffic was found for practically all substances under conditions of rural traffic, while - for some substances - under conditions of traffic on highways and expressways.

3. General conclusions based on the studies conducted show, that the estimation of average velocity values under model traffic conditions, for the purpose of quantifying emission from motor vehicles, can be a source of significant uncertainty in modeling results. This justifies the expediency of implementing an empirical research programme for vehicle traffic on a scale so that it is possible to formulate reliable conclusions about the representative characteristics of passenger car traffic.

\section{Nomenclature}

b specific distance emission

CI compression ignition

$\mathrm{E}_{\mathrm{a}} \quad$ national annual emission

$\mathrm{H}$ highway

$\mathrm{N}$ number of vehicles per cumulated category

skumulowanych

$\mathrm{p} \quad$ annual mileage of vehicles per cumulated category

PC passenger cars
PC-CI passenger cars - compression ignition (engine)

PC-SI passenger cars - spark ignition (engine)

$\mathrm{R}$ rural

$\mathrm{T}$ total (vehicles)

$\mathrm{u} \quad$ share of road travelled by vehicles per cumulated category under model traffic conditions

U urban

$\mathrm{v} \quad$ average velocity of vehicles per cumulated category

\section{Bibliography}

[1] BEBKIEWICZ, K., CHŁOPEK, Z., SZCZEPAŃSKI, K., ZIMAKOWSKA-LASKOWSKA, M. The influence of the properties of vehicles traffic on the total pollutant emission. Proceedings of the Institute of Vehicles. 2017, 1(110), 89102.

[2] BUWAL (Bundesamt für Umwelt, Wald und Landschaft), INFRAS AG (Infrastruktur-, Umwelt- und Wirtschaftsberatung). Luftschadstoffemissionen des Strassenverkehrs 19502010. BUWAL-Bericht Nr. 255, 1995.

[3] CHŁOPEK, Z., BIEDRZYCKI, J., LASOCKI, J., WÓJCIK, P. Comparative examination of pollutant emission from an Automotive internal combustion engine with the use of vehicle driving tests. Combustion Engines. 2016, 164(1), 5664.

[4] CHŁOPEK, Z., LASKOWSKI P. Pollutant emission characteristics determined using the Monte Carlo method. Eksploatacja $i$ Niezawodnosc - Maintenance and Reliability. 2009, 2(42), 42-51.

[5] CHŁOPEK, Z., ZIMAKOWSKA, M. Charakterystyki emisji zanieczyszczeń z samochodowych silników spalinowych. Rozdział w monografii „Współczesne problemy inżynierii i ochrony środowiska”. Zeszyt „Inżynieria Środowiska”.
Oficyna Wydawnicza Politechniki Warszawskiej. 2009, 55, 53-66.

[6] CHŁOPEK, Z. Modelowanie procesów emisji spalin w warunkach eksploatacji trakcyjnej silników spalinowych. Oficyna Wydawnicza Politechniki Warszawskiej. Prace Naukowe. Seria „Mechanika”. 1999, 173.

[7] CHŁOPEK, Z. Some remarks on engine testing in dynamic states. Combustion Engines. 2010, 143(4), 60-72.

[8] CHŁOPEK, Z. Zasady modelowania zużycia paliwa i energii oraz emisji zanieczyszczeń związanych $\mathrm{Z}$ użytkowaniem pojazdów drogowych. Technika Transportu Szynowego. 2015, 12, 262-267.

[9] COPERT Training 5. COPERT 5 vs COPERT 4. European Environment Agency. 2016. emisia.com/sites/default/files/ COPERT_5_features.pdf (accessed 2016.12.06).

[10] EMEP/EEA air pollutant emission inventory guidebook 2016. European Environment Agency. www.eea.europa.eu/ publications/emep-eea-guidebook-2016 (accessed 2016. 12.06).

[11] GKATZOFLIAS, D., KOURIDIS, CH., NTZIACHRISTOS, L., SAMARAS, Z. COPERT 4 Computer programme to calculate emissons from road transport. User manual (version 9.0). European Environment Agency. Emisia SA. 2012. (accessed 2016.12.06). 
[12] INFRAS AG. Handbook emission factors for road transport 3.2. Quick reference. Version 3.2. Bern, 2014.

[13] LASKOWSKI, P. Wyznaczanie charakterystyk emisji zanieczyszczeń w przypadkowych stanach pracy samochodowych silników spalinowych. Rozprawa doktorska. Politechnika Warszawska. Wydział Samochodów i Maszyn Roboczych. Warszawa 2015.

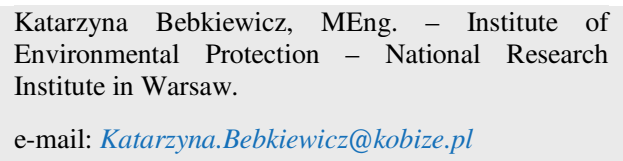

Prof. Zdzisław Chłopek, DSc., DEng. - Institute of Environmental Protection - National Research Institute in Warsaw.

e-mail: Zdzislaw.Chlopek@kobize.pl

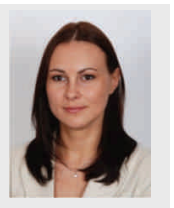
Environmental Protection - National Research

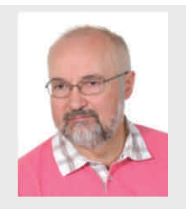

Grzegorz Stosio, Eng. - Faculty of Automotive and Construction Machinery Engineering in the Warsaw University of Technology.

e-mail: GrzegorzStosio@gmail.com
Krystian Szczepański, DSc., DEng. - Institute of Institute in Warsaw.

e-mail: Krystian.Szczepanski@ios.edu.pl

[14] PIELECHA, J. Identyfikacja parametrów cząstek stałych z silników spalinowych. Wydawnictwo Politechniki Poznańskiej. Poznań 2012.

[15] Worldwide emission standards. Passenger cars and light duty vehicles. Delphi. Innovation for the real world. 2016/2017.

[16] 2006 IPCC Guidelines for National Greenhouse Gas Inventories. www.ipcc-nggip.iges.or.jp/public/2006gl/vol2. html (accessed 2016.12.06).

Magdalena Zimakowska-Laskowska, DSc., DEng. -

Institute of Environmental Protection - National

Research Institute in Warsaw.

e-mail: Magdalena.Zimakowska-Laskowska@kobize.pl
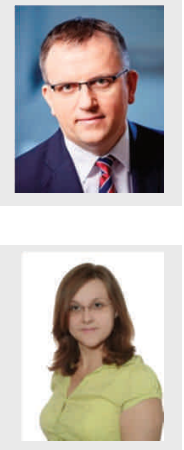

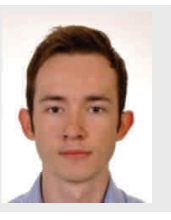

